Instructions for authors, subscriptions and further details:

http://ijep.hipatiapress.com

\title{
Revisiting the Antecedents of Social Entrepreneurial Intentions in Hong Kong
}

Ching Yin Ip ${ }^{1}$, Shih-Chia Wu ${ }^{2}$, Huei-Ching Liu ${ }^{1}$, Chaoyun Liang ${ }^{1}$

1) National Taiwan University

2) The Chinese University of Hong Kong

Date of publication: October $24^{\text {th }}, 2017$

Edition period: October 2017 - February 2018

To cite this article: Ip, C.Y.; Wu, S.-C.; Liu, H.-C. \& Liang, C. (2017).

Revisiting the Antecedents of Social Entrepreneurial Intentions in Hong Kong. International Journal of Educational Psychology, 6(3), 301-323. doi: 10.17583/ijep.2017.2835

To link this article: http://dx.doi.org/10.17583/ijep.2017.2835

\section{PLEASE SCROLL DOWN FOR ARTICLE}

The terms and conditions of use are related to the Open Journal System and to Creative Commons Attribution License (CC-BY). 


\section{Revisiting the Antecedents of Social Entrepreneurial Intentions in Hong Kong}

Ching Yin Ip

National Taiwan University

Huei-Ching Liu

National Taiwan University
Shih-Chia Wu

The Chinese University of Hong Kong

Chaoyun Liang

National Taiwan University

\section{Abstract}

This study examined how empathy, moral obligation, social entrepreneurial selfefficacy, perceived social support, and prior experience with social problems are associated with social entrepreneurial intentions. Through a survey, a sample of 252 Hong Kong students was used for analyses. Factor analyses supported that the antecedents of social entrepreneurial intentions could be divided into dimensions of empathy, moral obligation, social entrepreneurial self-efficacy, perceived social support, and prior experience with social problems. Multiple regression analysis results indicated that perceived social support was the most prominent antecedent of social entrepreneurial intentions, followed by moral obligation, empathy, and prior experience with social problems. Notably, moral obligation was revealed to be negatively associated with social entrepreneurial intentions.

Keywords: Empathy, moral obligation, self-efficacy, social support, prior experience, social enterprises 


\section{Revisitando los Antecedentes de las Intenciones de Emprendimiento Social en Hong Kong}

Ching Yin Ip

National Taiwan University

Huei-Ching Liu

National Taiwan University

\author{
Shih-Chia $\mathrm{Wu}$ \\ The Chinese University of Hong Kong \\ Chaoyun Liang \\ National Taiwan University
}

\section{Resumen}

Este estudio examinó cómo la empatía, la obligación moral, la autoeficacia empresarial social, el apoyo social percibido y la experiencia previa con problemas sociales están asociados con las intenciones empresariales sociales. A través de una encuesta, se utilizó una muestra de 252 estudiantes de Hong Kong. Los análisis factoriales respaldaron que los antecedentes de las intenciones empresariales sociales podrían dividirse en dimensiones de empatía, obligación moral, autoeficacia empresarial social, apoyo social percibido y experiencia previa con problemas sociales. Los resultados del análisis de regresión múltiple indicaron que el apoyo social percibido fue el antecedente más prominente de las intenciones empresariales sociales, seguido de la obligación moral, la empatía y la experiencia previa con problemas sociales. En particular, se reveló que la obligación moral se asociaba negativamente con las intenciones empresariales sociales.

Palabras clave: Empatía, obligación moral auto eficacia, apoyo social, experiencia previa, empresas sociales. 
everal problems in Hong Kong, such as the widening gap between the rich and poor, the ageing population, and the volatile economy, have facilitated the emergence of social enterprises. First, because of the emphasis on acquiring land- and development-related tax revenue, the high dependence on volatile financial and real estate industries has caused a highly skewed wealth distribution, so that wealthy people have become wealthier, whereas upward mobility for underprivileged people has decreased (Wissink, Koh, \& Forrest, 2017). Hence, alleviating poverty is a major social aim of social enterprises in Hong Kong (Chan, Kuan, \& Wang, 2011). Second, the Confucianism-based and collectivist culture of Hong Kong has made elderly people adopt a self-restrained attitude to avoid becoming a burden on the younger generation (Luo \& Chui, 2016), thus resulting in the demand for social enterprises that would employ elderly people. Third, the financial crisis and economic downturn since 1997 have caused an increase in welfare expenditure as well as a decrease in government funding for nongovernmental organisations, which has engendered a change in welfare philosophy and the rise of social enterprises in the region (Ho \& Chan, 2010).

Early research on 'social entrepreneurship' focused on the definitions and functions of the term (Dees, 1998; Mort, Weerawardena, \& Carnegie, 2003). In recent years, scholars have been more interested in the theoretical development of the causes of the intentions towards forming a social enterprise (Hockerts, 2017; Mair \& Noboa, 2006). Mair and Noboa (2006) suggested that empathy, moral judgement, social entrepreneurial selfefficacy, and perceived social support were the factors that could affect social entrepreneurial intentions. Hockerts (2017) extended the model of Mair and Noboa (2006) with the claim that prior experience with social problems could also predict social entrepreneurial intentions. These studies have provided a theoretical foundation for analysing social entrepreneurial intentions, but further inquiries are required to test its generalisability across contexts.

Scholars have emphasised the need for research on social entrepreneurship in Asia to provide a comprehensive picture about this concept in different cultural-geographical locations and in both internationally and locally embedded situations (Chell, Spence, Perrini, \& 


\section{Ip, Wu, Liu \& Liang-Social Entrepreneurial Intentions}

Harris, 2016; Liang, Chang, Liang, \& Liu, 2017); this thus motivated the current study. The aim of this study was to analyse the antecedents of social entrepreneurial intentions and their influences on Hong Kong university students. The research population is targeted because they are the future generation of Hong Kong society, and with passion in exploring different career options including social entrepreneurship. This the authors' wish that the present study can shed lights on the educational needs in encouraging university students to establish social enterprises.

\section{Literature Review}

\section{Social Entrepreneurial Intentions}

Among the different conceptualisations of social enterprises, two major types are mentioned herein. The first type conceptualises social enterprises as nonprofit organisations (NPOs), adopting a market-oriented approach (Defourny \& Kim, 2011). The second type regards social enterprises as profit-making enterprises whose objective is to address a social mission, and two features are involved, namely emphasising the economic value of the sustainability of social ventures and creating social value by providing solutions to social problems (Dacin, Dacin, \& Tracey, 2011). Although the first conceptualisation provides a clear typology of social enterprises in East Asia, it cannot clearly elucidate or distinguish between social enterprises and NPOs. Hence, to distinguish social enterprises from NPOs, the second conceptualisation was adopted in this study.

Intentional behaviours can help to understand the reasons of entrepreneurs who plan to start up a venture before they search for opportunities (Krueger, Reilly, \& Carsrud, 2000; Wang, Chang, Yao, \& Liang, 2016). Although entrepreneurial intentions are defined as 'a selfacknowledged conviction by a person that they intend to set up a new business venture and consciously plan to do so at some point in the future' (Thompson, 2009, p. 676), social entrepreneurial intentions in this study are defined as 'the self-acknowledged conviction and preparation by a person who intends to establish a new social venture'. When considering the aforementioned studies, this study referred to Wang, Peng, and Liang's 
(2014) scale of entrepreneurial intentions, which was based on the concepts of entrepreneurial conviction and preparation.

Early research provided the foundation for analysing social entrepreneurial intentions. Ajzen's (1991) theory of planned behaviour (TPB) has been widely adopted for understanding the antecedents of behavioural intentions, namely attitude towards the behaviour, subjective norm, and perceived behavioural control. On the basis of Ajzen's TPB, Mair and Noboa (2006) developed a theoretical framework of social entrepreneurial intentions and suggested that empathy, moral judgement, self-efficacy, and social support are the four antecedents of social entrepreneurial intentions; specifically, empathy serves as a substitute for attitude towards the behaviour, moral judgement as a substitute for subjective norm, self-efficacy as a substitute for perceived internal behavioural control, and social support as a substitute for perceived external behavioural control.

Hockerts (2017) extended Mair and Noboa's (2006) model by including one additional antecedent-prior experience with social problems. Moreover, two adjustments were made to Mair and Noboa's (2006) model. First, moral judgement was replaced by moral obligation, because moral judgement is more related to the reason why an individual feels morally obliged instead of the extent of that obligation (Hockerts, 2015). Second, perceived desirability and perceived feasibility were excluded from the model, because Hockerts (2017) determined them to not be separate factors in exploratory factor analysis. On the basis of the aforementioned studies, we tested the effects of five antecedents - empathy, moral obligation, social entrepreneurial self-efficacy, perceived social support, and prior experience with social problems - on the social entrepreneurial intentions of university students.

\section{Antecedents of Social Entrepreneurial Intentions}

Empathy is regarded as the 'natural ability to understand the emotions and feelings of others, whether one actually witnessed his or her situation, perceived it from a photograph, read about it in a fiction book, or merely imagined it' (Decety \& Jackson, 2004, p. 71). Wood (2012) indicated that empathy is a key driver for supporting social ventures and stresses social 


\section{Ip, Wu, Liu \& Liang-Social Entrepreneurial Intentions}

innovation. Additionally, empathetic entrepreneurs usually possess vital elements that are crucial for success, including the abilities to motivate and lead employees, assist employees in handling workplace stress, gain higher customer satisfaction through understanding customers' wants, and achieve higher innovativeness (Humphrey, 2013). Consequently, empathy, as one of the virtuous behaviours, is essential for a social entrepreneur to create social value for the organisation (Kraus, Filser, O’Dwyer, \& Shaw, 2014).

Moral obligation is 'a decision-making subprocess that occurs after an individual makes a moral judgment and prior to establishing a moral intention' (Haines, Street, \& Haines, 2008, p. 391). Strengthening moral obligations through increasing social awareness and responsibility can increase prosocial intentions and behaviour (De Groot \& Steg, 2009), which is consistent with the aim of social entrepreneurs in achieving prosocial goals through starting up their ventures (Stephan, Uhlaner, \& Stride, 2015). Kibler and Kautonen (2016) also claimed that higher self-evaluation of moral values might contribute to higher intentions to start up an enterprise. However, although ethical motives and moral responsibility are vital for social entrepreneurship, other motives may also involve less altruistic purposes such as personal fulfilment (Mair \& Marti, 2006). This could explain why the positive association of moral obligation with social entrepreneurial intentions was not supported in Hockert's (2017) study.

Social entrepreneurial self-efficacy is regarded as 'a person's belief that individuals can contribute toward solving societal problems' (Hockerts, 2017, p.109). Higher entrepreneurial self-efficacy was found to be associated with a higher level of conviction and preparation for establishing a new venture, including higher self-confidence in addressing entrepreneurial tasks and higher engagement in writing a business plan or saving money for the business (Sequeira, Mueller, \& McGee, 2007). In addition, potential social entrepreneurs in emerging markets were reported to exhibit high selfefficacy, because it was associated with a higher level of innovativeness, social impact, expandability, and sustainability of the venture (Urban, 2015). However, high self-efficacy may not always be beneficial for entrepreneurs. Entrepreneurs who are overconfident in dynamic environments may ignore or undervalue new information, which would in turn affect firm performance (Hmieleski \& Baron, 2008). 
The social support that entrepreneurs require is normally based on their social capital, because successful entrepreneurs rely on efficient networks (Mair \& Noboa, 2006). As suggested by Baron and Markman's (2000) concept of social capital, defined as the actual and potential resources gained from being part of a social network, social capital gained through reputation and personal contacts is associated with more access to venture capitalists and potential customers (Chia \& Liang, 2016). Additionally, social capital is paramount for greater knowledge acquisition, which is vital for newer firms (Yli-Renko, Autio, \& Sapienza, 2001) when social entrepreneurs require knowledge of market demands and needs and social innovation to address social problems (Austin, Stevenson, \& Wei-Skillern, 2006). Stam, Arzlanian, and Elfring (2014) added that connections to people of different backgrounds assist entrepreneurs of new firms to capture valuable resources to enhance firm performance.

Prior experience with social problems is regarded as people's practical experience in working with social-sector organisations, which can generate familiarity with such types of social problems (Hockerts, 2017). Prior experiences in self-employment and entrepreneurial education can be a trigger and a guide for potential entrepreneurs because such experiences nurture and encourage them to start up an enterprise (Keat, Selvarajah, \& Meyer, 2011). Furthermore, such experiences seem to enable social entrepreneurs to understand what works and what does not work before engaging in a new venture, identify role models, and develop confidence in establishing an enterprise (Shumate, Atouba, Cooper, \& Pilny, 2014). Khuong and An (2016) determined the positive association between prior entrepreneurial experiences and entrepreneurial intentions, demonstrating how entrepreneurship training and education might shape students' future professions.

Based on the aforementioned studies, the following five hypotheses were proposed:

H1. Empathy positively affects social entrepreneurial intentions of university students.

H2. Moral obligation positively affects social entrepreneurial intentions of university students. 
H3. Social entrepreneurial self-efficacy positively affects social entrepreneurial intentions of university students.

H4. Perceived social support positively affects social entrepreneurial intentions of university students.

H5. Prior experience with social problems positively affects social entrepreneurial intentions of university students.

\section{Method}

\section{Measures}

A quantitative method involving the use of a survey was adopted in this study. To ensure reliable and valid measurement, scales from previous studies were adopted. Regarding the antecedents of social entrepreneurial intentions, the study results of Hockert (2017) were referred to. A total of 15 questions were adopted as survey questions for measuring the concepts of empathy, moral obligation, social entrepreneurial self-efficacy, perceived social support, and prior experience with social problems (three items for each dimension). In addition, with reference to the study of Wang et al. (2014), social entrepreneurial intentions were measured by conviction and preparation dimensions through eight items. The respondents answered on a 6-point Likert-type scale ranging from 1 (strongly disagree) to 6 (strongly agree). Unanswered questions were treated as missing values.

\section{Participants and Procedures}

The survey used both online and offline channels. Students studying in Hong Kong and students who were born in Hong Kong but may not be currently studying in Hong Kong were our target respondents. A survey link was posted on Facebook fan pages for university students in Hong Kong. Moreover, the survey was distributed during classes at the Chinese University of Hong Kong. Consequently, a total of 303 questionnaires were received through both channels. Participation was voluntary, and anonymity was guaranteed. Before the execution of further analyses, 51 questionnaires with a high proportion of incomplete or contradictory viewpoints were excluded. Therefore, the total number of valid questionnaires was 252 .

The sample descriptive statistics are outlined as follows: Female participants constituted $62.3 \%$ of the sample; $31.9 \%$ and $55.8 \%$ of the 
participants were third-year and fourth-year (or higher) students, respectively, whereas the remaining participants were postgraduate students; $26.5 \%$ and $69.5 \%$ of the participants were aged 20 years or younger and $21-$ 25 years, respectively, whereas the remaining participants were aged 26 years or older; and $83.3 \%$ and $10.0 \%$ of the participants were born in Hong Kong and mainland China, respectively. Regarding the areas of study, social science majors constituted the majority (45.6\%), followed by business administration (31.7\%) and science and engineering (9.9\%). Principal component analysis with varimax rotation was performed to test the dimensionality of the concepts with the adoption of SPSS 23.0 statistical software. Multiple regression analysis was then performed to analyse the possible causal relationships between the variables.

\section{Exploratory Factor Analysis}

\section{Results}

The Kaiser-Meyer-Olkin (KMO) value of the antecedents of social entrepreneurial intentions was 0.88. Bartlett's test of sphericity was significant $\left(\chi^{2}=2225.70, d f=105, p<.001\right)$, implying that the data were appropriate for factor analysis. According to Table 1, the total variance explained for the five factors-empathy, moral obligation, social entrepreneurial self-efficacy, perceived social support, and prior experience with social problems - was $77.43 \%$, revealing adequate validity. Hence, the study provided a scale for analysing the antecedents of the social entrepreneurial intentions of Chinese-speaking university students on the basis of Hockert's (2017) five determinants of social entrepreneurial intentions. A factor loading less than .3 is blanked. 
Table 1.

Factor analysis of antecedents of social entrepreneurial intentions $(n=252)$

$\%$ of 1. 2. 3. 4. 5. $M \quad S D \sigma^{2}$

1. Empathy $(\alpha=.80)$

12.62

I feel compassion for socially marginalised ${ }^{58} \quad .47$

people.

4.51 .92

When thinking about socially disadvantaged ${ }_{.77}$

people, I try to put myself in their shoes.

Seeing socially disadvantaged people triggers an ${ }^{68} \quad .48$ emotional response in me.

2. Moral obligation $(\alpha=.90)$

We are morally obliged to help socially ${ }^{36} \quad .75$ disadvantaged people.

It is an ethical responsibility to help people less fortunate than ourselves.

Social justice requires that we help those who are less fortunate than ourselves.

3. Social entrepreneurial self-efficacy $(\alpha=$.77)

Promoting environmental sustainability is something each of us can contribute to.

$.49 \quad .76$

I am convinced that I personally can make a contribution to address environmental sustainability if I put my mind to it.

I could figure out a way to help solve the environmental issues.

\section{Perceived social support $(\alpha=.82)$}

It is possible to attract investors for an organisation that wants to promote environmental sustainability.

People would support me if I wanted to start an organization to help socially marginalised people. If I planned to address a significant environmental problem, people would back me up.

5. Prior experience with social problems $(\alpha=.82)$

I have volunteered or otherwise worked with social organisations.

$.76 \quad .32$

.62 .47

3.80 .97

16.96

$.73 \quad 3.79 .99$

$.81 \quad 3.88 .96$

$.87 \quad 3.77 .98$

I have some experience working with social problems.

$.88 \quad 3.811 .11$

I know a lot about social organizations.

$.79 \quad 3.971 .00$

Total variance explained

77.43


The KMO value of social entrepreneurial intentions was 0.89. Bartlett's test of sphericity was significant $\left(\chi^{2}=1678.27, d f=28, p<.001\right)$, implying that the sample was appropriate for factor analysis. According to Table 2, the total variance explained of the single factor was $68.26 \%$, which showed adequate validity. Therefore, this study provided a tool for analysing social entrepreneurial intentions.

Table 2.

Factor analysis of social entrepreneurial intentions $(n=252)$

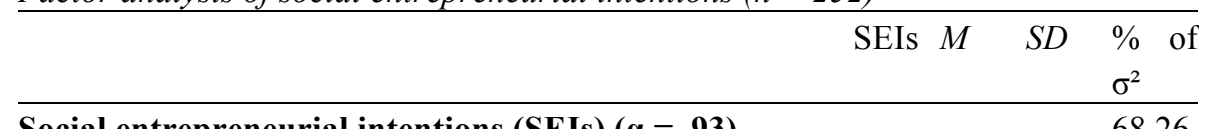

Social entrepreneurial intentions (SEIs) $(\alpha=.93)$ 68.26

I wish to start a social enterprise that assist in alleviating.67 $\quad 3.73 \quad 1.11$ environmental issues.

I have a preliminary idea for a social enterprise on which I.83 $\quad 3.19 \quad 1.12$ plan to act in the future.

$\begin{array}{llll}\text { My professional goal is to become a social entrepreneur. } & .90 & 2.82 & 1.04\end{array}$ $\begin{array}{llll}\text { I am going to do anything to become a social entrepreneur. } & 90 & 2.89 & 1.13\end{array}$

I expect that at some point in the future I will be involved.89 $3.00 \quad 1.10$ in launching an organization that aims to promote environmental sustainability.

I expect that at some point in the future I will be involved.84 $3.19 \quad 1.17$ in launching an organization that aims to help disadvantaged groups.

I will act as a professional manager in getting involved in.86 $\quad 3.05 \quad 1.12$ management of a social enterprise through promotion.

If I am going to inherit my family's business, I will plan to.69 $3.12 \quad 1.15$ transform it into a social enterprise.

Note 1: Because only one component was extracted with eigenvalues greater than 1, factor loadings of social entrepreneurial intentions can be shown only through principal component analysis. 


\section{Ip, Wu, Liu \& Liang-Social Entrepreneurial Intentions}

\section{Multiple Regression Analysis}

Multiple regression analysis was conducted to analyse the effects of the antecedents on social entrepreneurial intentions. According to Table 3, the unstandardised regression coefficients of empathy, moral obligation, perceived social support, and prior experience with social problems on social entrepreneurial intentions reached $.278(p<.01),-.282(p<.001), .540(p<$ $.001)$ and $.137(p<.05)$, respectively. Because empathy, perceived social support, and prior experience with social problems were positively associated with social entrepreneurial intentions, $\mathrm{H} 1, \mathrm{H} 4$, and $\mathrm{H} 5$ were supported. Although moral obligation was significantly associated with social entrepreneurial intentions, the association was negative; hence, $\mathrm{H} 2$ was rejected. Furthermore, because social entrepreneurial self-efficacy did not reveal significant effects on social entrepreneurial intentions, H3 was rejected. The $R^{2}$ value of independent variables to social entrepreneurial intentions reached $33.2 \%$, and the results of the F-test reached the level of significance $(p<.001)$, implying that the regression model was appropriate.

Table 3.

Multiple regression analysis of the effects of the antecedents on social entrepreneurial intentions $(n=252)$

\begin{tabular}{|c|c|c|c|c|}
\hline \multirow[t]{2}{*}{ Variables } & & \multicolumn{3}{|c|}{ Social Entrepreneurial intentions } \\
\hline & & Beta & $t$ & $p$ \\
\hline \multirow{10}{*}{ Antecedents } & (Constant) & .712 & 2.145 & $.033^{*}$ \\
\hline & Empathy & .278 & 2.941 & $0.004 * *$ \\
\hline & Moral obligation & -.282 & - & $.001 * * *$ \\
\hline & & & 3.303 & \\
\hline & $\begin{array}{l}\text { Social entrepreneurial self- } \\
\text { efficacy }\end{array}$ & -.034 & -.401 & .688 \\
\hline & Perceived social support & .540 & 7.673 & $.000 * * *$ \\
\hline & $\begin{array}{l}\text { Prior experience with social } \\
\text { problems }\end{array}$ & .137 & 2.158 & $.032 *$ \\
\hline & $R^{2}$ & .332 & & \\
\hline & $F$ & 24.493 & & \\
\hline & $p$ & $.000 * * *$ & & \\
\hline
\end{tabular}




\section{Discussion}

Factor analysis revealed five dimensions of the antecedents of social entrepreneurial intentions, namely empathy, moral obligation, social entrepreneurial self-efficacy, perceived social support, and prior experience with social problems. This supports the factor structures suggested by Mair and Noboa (2006) and Hockerts (2017). However, social entrepreneurial intentions could not be divided into the two factors proposed by Wang et al. (2014). This is probably because their study focused on entrepreneurship rather than social entrepreneurship.

The regression model was determined to be appropriate. First, the $p$ value of the overall $F$-test was significant, indicating that the variables of the antecedents of social entrepreneurial intentions did contribute to a superior model to the intercept-only model. Second, the independent variables (antecedents) accounted for $33.2 \%$ of the variance in social entrepreneurial intentions, signifying an acceptable explanatory power of the model.

Perceived social support was observed to be a vital factor in promoting social entrepreneurial intentions, and this is in agreement with the findings of Mair and Noboa (2006) and Hockerts (2017). Social entrepreneurs can never succeed alone (Mair \& Noboa, 2006), especially in the collectivist culture of Hong Kong that emphasises social harmony and common goals (Oyserman, Coon, \& Kemmelmeier, 2002). With a higher level of social support through connections with diverse individuals, entrepreneurs can obtain valuable resources to enhance firm performance (Stam et al., 2014). For example, social capital can contribute to attaining a high probability of success in crowdfunding (Zheng, $\mathrm{Li}, \mathrm{Wu}, \& \mathrm{Xu}, 2014$ ), which is an emerging financial source for social enterprises (Calic \& Mosakowski, 2016). Accordingly, educators should assist students in developing social networks for public support for alleviating social problems (Mair \& Marti, 2006) and in facing work-related stress in entrepreneurial ventures (Batjargal, Hitt, Tsui, Arregle, Webb, \& Miller, 2013).

Empathy was also determined to be a significant factor for raising social entrepreneurial intentions, and this is in agreement with Hockerts' (2017) student samples. Because empathy is crucial for motivating employees and understanding customer needs (Humphrey, 2013), potential social entrepreneurs should initiate their business with a higher chance for success 


\section{Ip, Wu, Liu \& Liang-Social Entrepreneurial Intentions}

because daily operations and profit earning are necessary for venture sustainability. Because a common objective of Hong Kong social enterprises is to mitigate poverty (Chan et al., 2011), emotional connections with those suffering are required to develop a prosocial identity for the commitment to act to relieve poverty (Miller, Grimes, McMullen, \& Vogus, 2012). To foster student empathy in order to equip them to become social entrepreneurs, educators may consider conducting alternative class activities such as a poverty simulations to raise students' attention to social problems (Nickols \& Nielsen, 2011) and engaging students in team sports, which allow them to cooperate with others and compassionately understand others' perspectives (Gano-Overway, 2014).

Prior experience with social problems was another significant factor contributing to social entrepreneurial intentions, and this is consistent with Hockerts' (2017) finding. This is also in line with how prior experience facilitates the generation of awareness and knowledge of the social aspects for opportunity development of social ventures (Corner \& Ho, 2010), as well as with the importance of prior education and volunteering experience in forming a social venture (Shumate et al., 2014). Nevertheless, the effect of this variable is comparably weak. This is possibly because Hong Kong students may not have sufficient experience with social problems because of the pragmatic predisposition in learning (Kennedy, 2002). Fostering servicelearning in universities, which integrates academic study with community service, could be a means of raising student responsibility for and awareness of social changes (Ngai, 2006). Another possible reason is that Hockerts (2017) believed that prior experience and social entrepreneurial intentions are mediated by the four antecedents proposed by Mair and Noboa (2006). How prior experience affects social entrepreneurial intentions warrants further inquiry.

Social entrepreneurial self-efficacy was not found to be associated with social entrepreneurial intentions in the present study, contradicting the findings of Mair and Noboa (2006) and Hockerts (2017). Hockerts (2017) found that social entrepreneurial self-efficacy was a dominant predictor of social entrepreneurial intentions in his two student samples. One explanation could be that Hockerts' (2017) respondents were from Western countries, characterised by an individualistic culture. Comparatively, our respondents 
were strongly affected by the Oriental collectivist culture, where individual self-efficacy may be lessened by a person's perception of others' attitudes (perceived social norms) towards entrepreneurial intentions (Siu \& Lo, 2013). By adopting Ajzen's TPB to predict entrepreneurial intentions in 12 countries, Engle et al. (2010) also reported that entrepreneurial self-efficacy had no significant associations with entrepreneurial intentions in their Chinese sample. The aforementioned studies provided the basis of our finding.

Notably, moral obligation was observed to be negatively associated with social entrepreneurial intentions, which contradicts the initial claim of Mair and Noboa (2006). However, one of Hockerts' (2017) investigated samples shared a similar negative result; therefore, examining the reasons behind it is worthwhile. One major argument is that the motive to engage in social entrepreneurship must not necessarily be morally obliged. The motive may involve less altruistic reasons including personal fulfilment, such as the desire for status, recognition, respect, and friendship (Bacq, Hartog, \& Hoogendoorn, 2016; Mair \& Marti, 2006). Another possible reason is that perception matters. For example, those who indicate that they do not strongly agree with the statement 'social justice requires that we help those who are less fortunate than ourselves' may actually perceive helping social minorities as insufficient for establishing social justice because other factors such as environmental and juvenile issues also matter.

This study has two limitations. First, we received a relatively high proportion of questionnaires from a single university, because the offline survey was distributed at the Chinese University of Hong Kong, which may not entirely represent the university population in Hong Kong. Second, because of the lack of established social entrepreneurial intention scales, we developed our own by modifying an existing entrepreneurial intention scale (Wang et al., 2014), which may require further adjustments to suit the social entrepreneurial context.

To address the aforementioned limitations, future studies can adopt a sample with students from different universities or even a sample of the Hong Kong public to examine how these variables are associated with social entrepreneurial intentions. Because Hockerts (2017) suggested that the four antecedents proposed by Mair and Noboa (2006) can mediate prior 


\section{Ip, Wu, Liu \& Liang-Social Entrepreneurial Intentions}

experience and social entrepreneurial intentions, we aspire to evaluate whether similar results can be attained for Hong Kong respondents. In addition, a social entrepreneurial intention scale should be established to enrich the literature on social entrepreneurship and facilitate measurements.

\section{Conclusion}

In summary, the results indicate that empathy, perceived social support, and prior experience with social problems were positively associated with social entrepreneurial intentions, whereas no significant association was found between social entrepreneurial self-efficacy and social entrepreneurial intentions. Notably, moral obligation was revealed to be negatively associated with social entrepreneurial intentions.

These results lead to several evident contributions. First, this is the first study to adopt Hockerts' (2017) model and test it in an Asian context. Our results partially support the model and indicate promising directions for future research. Second, the present study not only enriches the theoretical base of social entrepreneurship but also illustrates the need to reconsider the roles of moral obligation and entrepreneurial self-efficacy. Third, our results have beneficial practical implications for entrepreneurial educators in terms of designing appropriate instructional strategies and developing meaningful projects to nurture student potential and empower their entrepreneurial careers.

Social problems in this globalised era are not limited to a single individual or community but affect everyone worldwide. These problems can only be relieved when public awareness and support exist. Additionally, social connections have become fundamental for completing different tasks; whether they are trivial or enormous, such as establishing a social enterprise, gaining social support for assistance has become crucial. Although individual virtues such as empathy are also critical to encourage entrepreneurs to start up social ventures, no one can succeed without others' help to maintain venture sustainability. Because university students are our society's future, they should be encouraged to treasure environmental resources and help disadvantaged people. Social ventures are a new means of alleviating social problems with social innovation. This article has merely 
begun to emphasise the driving force for students' social entrepreneurial intentions, although future demand and potential for enriching the social entrepreneurship literature still exist.

\section{Acknowledgements}

The first draft of this manuscript will be presented at the 2017 International Conference of Taiwan Association for Educational Communications and Technology. The authors would like to express their gratitude for the insightful suggestions of anonymous 2017TAECT and the International Journal of Educational Psychology reviewers.

\section{References}

Ajzen, I. (1991). The theory of planned behavior. Organizational Behavior and Human Decision Processes, 50(6), 179-211. doi:10.1016/07495978(91)90020-T.

Austin, J., Stevenson, H., \& Wei-Skillern, J. (2006). Social and commercial entrepreneurship: Same, different, or both? Entrepreneurship Theory and Practice, 30(1), 1-22. doi:10.1111/j.1540-6520.2006.00107.x.

Bacq, S., Hartog, C., \& Hoogendoorn, B. (2016). Beyond the moral portrayal of social entrepreneurs: An empirical approach to who they are and what drives them. Journal of Business Ethics, 133(4), 703718. doi: 10.1007/s10551-014-2446-7.

Baron, R. A., \& Markman, G. D. (2000). Beyond social capital: How social skills can enhance entrepreneurs' success. The Academy of

Management Executive, 14(1), 106-116.

doi:10.5465/AME.2000.2909843.

Batjargal, B., Hitt, M. A., Tsui, A. S., Arregle, J. L., Webb, J. W., \& Miller, T. L. (2013). Institutional polycentrism, entrepreneurs' social networks, and new venture growth. Academy of Management Journal, 56(4), 1024-1049. doi:10.5465/amj.2010.0095.

Calic, G., \& Mosakowski, E. (2016). Kicking off social entrepreneurship: How a sustainability orientation influences crowdfunding success. 
318 Ip, Wu, Liu \& Liang-Social Entrepreneurial Intentions

Journal of Management Studies, 53(5), 738-767.

doi:10.1111/joms.12201.

Chan, K. T., Kuan, Y. Y., \& Wang, S. T. (2011). Similarities and divergences: Comparison of social enterprises in Hong Kong and Taiwan. Social Enterprise Journal, 7(1), 33-49. doi:10.1108/17508611111130149.

Chell, E., Spence, L. J., Perrini, F., \& Harris, J. D. (2016). Social entrepreneurship and business ethics: Does social equal ethical? Journal of Business Ethics, 133(4), 619-625. doi:10.1007/s10551-0142439-6.

Chia, C.-C. \& Liang, C. (2016). Influence of creativity and social capital on the entrepreneurial intention of tourism students. Journal of Entrepreneurship, Management and Innovation, 12(2), 151-168.

Corner, P. D., \& Ho, M. (2010). How opportunities develop in social entrepreneurship. Entrepreneurship Theory and Practice, 34(4), 635659. doi:10.1111/j.1540-6520.2010.00382.x.

Dacin, M. T., Dacin, P. A., \& Tracey, P. (2011). Social entrepreneurship: A critique and future directions. Organization Science, 22(5), 12031213. doi:10.1287/orsc.1100.0620.

De Groot, J. I., \& Steg, L. (2009). Morality and prosocial behavior: The role of awareness, responsibility, and norms in the norm activation model. The Journal of Social Psychology, 149(4), 425-449. doi:10.3200/SOCP.149.4.425-449.

Decety, J., \& Jackson, P. L. (2004). The functional architecture of human empathy. Behavioral and Cognitive Neuroscience Reviews, 3(2), 71100. doi: 10.1177/1534582304267187.

Dees, J. G. (1998). The meaning of “social entrepreneurship”. Stanford University: Draft Report for the Kauffman Center for Entrepreneurial Leadership.

Defourny, J., \& Kim, S. Y. (2011). Emerging models of social enterprise in Eastern Asia: A cross-country analysis. Social Enterprise Journal, 7(1), 86-111. doi:10.1108/17508611111130176.

Engle, R. L., Dimitriadi, N., Gavidia, J. V., Schlaegel, C., Delanoe, S., Alvarado, I., ... Wolff, B. (2010). Entrepreneurial intent: A twelvecountry evaluation of Ajzen's model of planned behavior. 
International Journal of Entrepreneurial Behavior \& Research, 16(1), 35-57. doi:10.1108/13552551011020063.

Gano-Overway, L. A. (2014). The caring climate: How sport environments can develop empathy in young people. In K. Pavlovich \& K. Krahnke (Eds.), Organizing through empathy (pp. 166-183). New York, NY: Routledge.

Haines, R., Street, M. D., \& Haines, D. (2008). The influence of perceived importance of an ethical issue on moral judgment, moral obligation, and moral intent. Journal of Business Ethics, 81(2), 387-399. doi:10.1007/s10551-007-9502-5.

Hmieleski, K. M., \& Baron, R. A. (2008). When does entrepreneurial selfefficacy enhance versus reduce firm performance? Strategic Entrepreneurship Journal, 2(1), 57-72. doi:10.1002/sej.42.

Ho, A. P. Y., \& Chan, K. T. (2010). The social impact of work-integration social enterprise in Hong Kong. International Social Work, 53(1), 3345. doi:10.1177/0020872809348950.

Hockerts, K. (2015). Antecedents of social entrepreneurial intentions: A validation study. Social Enterprise Journal, 11(3), 260-280. doi:10.5465/AMBPP.2013.16805abstract.

Hockerts, K. (2017). Determinants of social entrepreneurial intentions. Entrepreneurship Theory and Practice, 41(1), 105-130. doi:10.1111/etap.12171.

Humphrey, R. H. (2013). The benefits of emotional intelligence and empathy to entrepreneurship. Entrepreneurship Research Journal, 3(3), 287-294. doi:10.1515/erj-2013-0057.

Keat, O. Y., Selvarajah, C., \& Meyer, D. (2011). Inclination towards entrepreneurship among university students: An empirical study of Malaysian university students. International Journal of Business and Social Science, 2(4), 206-220.

Kennedy, P. (2002). Learning cultures and learning styles: Mythunderstandings about adult (Hong Kong) Chinese learners. International Journal of Lifelong Education, 21(5), 430-445. doi:10.1080/02601370210156745.

Khuong, M. N., \& An, N. H. (2016). The factors affecting entrepreneurial intention of the students of Vietnam National University: A mediation 
analysis of perception toward entrepreneurship. Journal of Economics, Business and Management, 4(2), 104-111. doi:10.7763/JOEBM.2016.V4.375.

Kibler, E., \& Kautonen, T. (2016). The moral legitimacy of entrepreneurs: An analysis of early-stage entrepreneurship across 26 countries. International Small Business Journal, 34(1), 34-50. doi:10.1177/0266242614541844.

Kraus, S., Filser, M., O’Dwyer, M., \& Shaw, E. (2014). Social entrepreneurship: An exploratory citation analysis. Review of Managerial Science, 8(2), 275-292. doi:10.1007/s11846-013-0104-6. Krueger, N. F., Reilly, M. D., \& Carsrud, A. L. (2000). Competing models of entrepreneurial intentions. Journal of Business Venturing, 15(5), 411-432. doi: 10.1016/S0883-9026(98)00033-0.

Liang, C., Chang, C.-C., Liang, C.-T., \& Liu, Y.-C. (2017). Imagining future success: Imaginative capacity on the perceived performance of potential agrisocio entrepreneurs. Thinking Skills and Creativity, 23, 161-174. doi:10.1016/j.tsc.2016.12.007.

Luo, M., \& Chui, E. W. T. (2016). An alternative discourse of productive aging: A self-restrained approach in older Chinese people in Hong Kong. Journal of Aging Studies, 38, 27-36. doi:10.1016/j.jaging.2016.04.002.

Mair, J., \& Marti, I. (2006). Social entrepreneurship research: A source of explanation, prediction, and delight. Journal of World Business, 41(1), 36-44. doi:10.1016/j.jwb.2005.09.002.

Mair, J., \& Noboa, E. (2006). Social entrepreneurship: How intentions to create a social venture are formed. In J. Mair, J. Robinson \& K. N. Hockerts (Eds.), Social entrepreneurship (pp. 121-135). Basingstoke, U.K.: Palgrave MacMillan.

Miller, T. L., Grimes, M. G., McMullen, J. S., \& Vogus, T. J. (2012).

Venturing for others with heart and head: How compassion encourages social entrepreneurship. Academy of Management Review, 37(4), 616-640. doi:10.5465/amr.2010.0456.

Mort, G., Weerawardena, J., \& Carnegie, K. (2003). Social entrepreneurship: Towards conceptualisation. International Journal of Nonprofit and Voluntary Sector Marketing, 8(1), 76-88. doi:10.1002/nvsm.202. 
Ngai, S. S. Y. (2006). Service-learning, personal development, and social commitment: A case study of university students in Hong Kong. Adolescence, 41(161), 165-176.

Nickols, S. Y., \& Nielsen, R. B. (2011). So many people are struggling: Developing social empathy through a poverty simulation. Journal of Poverty, 15(1), 22-42. doi:10.1080/10875549.2011.539400.

Oyserman, D., Coon, H. M., \& Kemmelmeier, M. (2002). Rethinking individualism and collectivism: Evaluation of theoretical assumptions and meta-analyses. Psychological Bulletin, 128(1), 3-72. doi:10.1037/0033-2909.128.1.3.

Sequeira, J., Mueller, S. L., \& McGee, J. E. (2007). The influence of social ties and self-efficacy in forming entrepreneurial intentions and motivating nascent behavior. Journal of Developmental Entrepreneurship, 12(3), 275-293. doi:10.1142/S108494670700068X.

Shumate, M., Atouba, Y., Cooper, K. R., \& Pilny, A. (2014). Two paths diverged: Examining the antecedents to social entrepreneurship. Management Communication Quarterly, 28(3), 404-421. doi:10.1177/0893318914538561.

Siu, W. S., \& Lo, E. S. C. (2013). Cultural contingency in the cognitive model of entrepreneurial intention. Entrepreneurship Theory and Practice, 37(2), 147-173. doi:10.1111/j.1540-6520.2011.00462.x.

Stam, W., Arzlanian, S., \& Elfring, T. (2014). Social capital of entrepreneurs and small firm performance: A meta-analysis of contextual and methodological moderators. Journal of Business Venturing, 29(1), 152-173. doi:10.1016/j.jbusvent.2013.01.002.

Stephan, U., Uhlaner, L. M., \& Stride, C. (2015). Institutions and social entrepreneurship: The role of institutional voids, institutional support, and institutional configurations. Journal of International Business Studies, 46(3), 308-331. doi:10.1057/jibs.2014.38.

Thompson, E. R. (2009). Individual entrepreneurial intent: Construct clarification and development of an internationally reliable metric. Entrepreneurship Theory and Practice, 33(3), 669-694. doi:10.1111/j.1540-6520.2009.00321.x. 
Urban, B. (2015). Evaluation of social enterprise outcomes and self-efficacy. International Journal of Social Economics, 42(2), 163-178. doi:10.1108/IJSE-03-2013-0071.

Wang, J.-H., Chang, C.-C., Yao, S.-N., \& Liang, C. (2016). The contribution of self-efficacy to the relationship between personality traits and entrepreneurial intention. Higher Education: The International Journal of Higher Education Research, 72(2), 209-224. doi:10.1007/s10734-015-9946-y.

Wang, J.-H., Peng, L.-P., \& Liang, C. (2014). Developing and testing the psychological variable, rural practice, and entrepreneurial intentions scales. Review of Agricultural Extension Science, 31, 72-95.

Wissink, B., Koh, S. Y., \& Forrest, R. (2017). Tycoon city: Political economy, real estate and the super-rich in Hong Kong. In R. Forrest, S. Y. Koh \& B. Wissink (Eds.), Cities and the super-rich: Real estate, elite practices and urban political economies (pp. 229-252). New York, NY: Palgrave Macmillan.

Wood, S. (2012). Prone to progress: Using personality to identify supporters of innovative social entrepreneurship. Journal of Public Policy \& Marketing, 31(1), 129-141. doi:10.1509/jppm.11.060.

Yli-Renko, H., Autio, E., \& Sapienza, H. J. (2001). Social capital, knowledge acquisition, and knowledge exploitation in young technology-based firms. Strategic Management Journal, 22(6-7), 587613. doi:10.1002/smj.183.

Zheng, H., Li, D., Wu, J., \& Xu, Y. (2014). The role of multidimensional social capital in crowdfunding: A comparative study in China and US. Information \& Management, 51(4), 488-496.

doi:10.1016/j.im.2014.03.003. 
Ching Yin Ip is Research Assistant, Department of Bio-Industry Communication and Development, National Taiwan University.

Shih-Chia Wu is Professional Consultant, School of Journalism and Communication, The Chinese University of Hong Kong.

Huei-Ching Liu is Research Assistant, Department of Bio-Industry Communication and Development, National Taiwan University.

Chaoyun Liang is Professor, Department of Bio-Industry Communication and Development, National Taiwan University. ORCID: 0000-0001-6608-7717.

Contact Address: Chaoyun Liang, Department of Bio-Industry Communication and Development, National Taiwan University, No. 1, Sec. 4, Roosevelt Road, Taipei, 10617, Taiwan. Email: cliang@ntu.edu.tw 